\title{
Advantages and disadvantages of the Italian entrepreneurial talents
}

Les talents de l'entrepreneuriat italien, avantages et désavantages

Gli aspetti originali dell'imprenditorialità italiana

\section{Vera Zamagni}

\section{OpenEdition}

\section{Journals}

Electronic version

URL: https://journals.openedition.org/ceb/10626

DOI: 10.4000/ceb.10626

ISSN: 2261-4184

\section{Publisher}

INALCO

\section{Printed version}

ISBN: 978-2-85831-294-8

ISSN: 0290-7402

\section{Electronic reference}

Vera Zamagni, "Advantages and disadvantages of the Italian entrepreneurial talents", Cahiers

balkaniques [Online], 45 | 2018, Online since 05 December 2018, connection on 21 September 2021

URL: http://journals.openedition.org/ceb/10626 ; DOI: https://doi.org/10.4000/ceb.10626

This text was automatically generated on 21 September 2021.

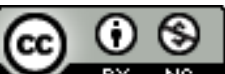

Cahiers balkaniques est mis à disposition selon les termes de la Licence Creative Commons Attribution - Pas d'Utilisation Commerciale 4.0 International. 


\title{
Advantages and disadvantages of the Italian entrepreneurial talents
}

\author{
Les talents de l'entrepreneuriat italien, avantages et désavantages \\ Gli aspetti originali dell'imprenditorialità italiana
}

Vera Zamagni

\section{The structure of the Italian economy}

1 Italian industry has very ancient roots, going back to the Middle Ages, when the Italian merchants conquered European markets with their manufactured products, becoming leaders in Europe for cultural, artistic, technical and economic innovations. Italian manufacturing later declined, although it did not disappear altogether, especially in the manufacture of silk, and resurrected at the end of the $19^{\text {th }}$ century, some decades after the unification of the country. Italian entrepreneurs have been capable since take off (1884-1913) to modernize, adopting international technology and occasionally contributing to innovation in specific fields (electricity, chemicals, engineering), but they have normally kept their firms smaller than in the rest of the advanced world. Big businesses have been exceptional and, as a result of WWI and the 1929 crisis, most of them fell in the hands of the State that produced a very original bailing out operation ended with the creation of a public holding called IRI ${ }^{1}$, which controlled $40 \%$ of the Italian joint stock companies of the time. The reconstruction after WWII confirmed IRI and developed other state-owned holdings (ENI, EFIM, ENEL are the most important ones) shaping a dualism of the Italian industrial sector: big business was in the hands of the State (SOEs), with very few exceptions (Fiat, Pirelli, Olivetti), while private enterprise managed the very large amount of SMEs ${ }^{2}$.

2 The management of big business by the Italian State did not show the same degree of effectiveness of its French counterpart, but it was not entirely negative. Among the 9 largest Italian companies appearing in the Fortune list of the Global 500 in 2013, 6 are former SOEs partly privatized, and one is still $100 \%$ state-owned. Among the largest and most successful former SOEs, Finmeccanica ${ }^{3}$ stands out as the most technologically 
advanced (it produces helicopters, aircrafts components, missiles, satellites, electronic systems for defence and aviation, space instruments). It has some joint ventures with the French Thales, and has acquired the British Helicopter company Westland, and the American defence company DRS. But the control by the State of the largest Italian enterprises had two perverse effects:

- a) It prevented the formation of a class of managers capable of administering big business, because state managers were too protected and "parochial" to be able to contribute to the privatization wave. This meant that during privatization since the 1990 ' it was not easy to find "private" managers capable of making the old SOEs competitive.

-b) It prevented the internationalization of Italian industry, because SOEs remained "national" and this remains a problem largely unsolved even today.

Private enterprises being practically confined in Italy to SMEs tried to reach excellency under this size constraint using two instruments, specialization and networks. Italian SMEs started specializing in all those sectors in which design and customization mattered, taking advantage of the centuries old manufacturing traditions and of the artistic heritage of the country. Italian SMEs have become famous in the world not only for the highly differentiated consumer goods (the "made in Italy" fashion), but also for engineering and chemical products tailored to the needs of their clients. They have also been capable of exploiting the implication of the electronic revolution that has exploded the process of production at the world level, becoming suppliers of components for many multinational corporations. Perhaps the best example is the Brembo company from Bergamo, which produces brakes for all the automobile and motorcar companies of the world.

Not being able to exploit economies of scale because of their limited size, Italian entrepreneurs have tried to exploit economies of scope, but not in one single plant (as it happens in corporations), rather building up tight networks. Networks can be of different type; in Italy, the practice of networks has been extensive particularly in two versions: industrial districts (geographical clusters) and what has been named "fourth capitalism". The industrial districts are a geographical conglomeration of SMEs specialized in different versions of the same product: the place becomes a permanent exhibition of all the varieties of one single product. We have a ceramic district in Sassuolo, a spectacles district in Friuli, a packaging machinery district in Bologna, a bicycle saddles district in Veneto, and other hundreds of them spread around North and Central Italy (only a few exist in the South, among which a sofas district in Puglia) ${ }^{4}$. "Fourth capitalism" is instead less geographically defined phenomenon including a few thousands medium size companies ${ }^{5}$ capable of internationalising and becoming world leaders in final products, outsourcing the production of intermediate parts to the smaller producers of the area $^{6}$. They are also called "pocket multinationals".

5 Italy has become highly competitive in a large number of "niche" products (about 1000), which have allowed the country to support exports, even across the present crisis. This is why Italy still has industry, as table 1 shows.

Table 1: Some comparative economic indicators

Some comparative economic indicators 


\begin{tabular}{|c|c|c|c|c|c|c|c|c|}
\hline & $\begin{array}{l}\text { Exports of } \\
\text { manufacturd } \\
\text { goods Billions } \\
\text { Euros }\end{array}$ & \begin{tabular}{|l} 
Trade \\
balance, \\
Total \\
products \\
Billions \\
euros
\end{tabular} & $\begin{array}{l}\text { Manufac- } \\
\text { turing } \\
\text { Production } \\
\text { Billions euros }\end{array}$ & \multicolumn{2}{|c|}{$\begin{array}{l}\text { Per capita } \\
\text { GNP } \\
E U=100\end{array}$} & $\begin{array}{l}\text { Mean wealth } \\
\text { per adult } \\
\text { Thousands } \$\end{array}$ & \multicolumn{2}{|c|}{$\begin{array}{l}\text { Public } \\
\text { Debt As } \\
\text { \%of GDP }\end{array}$} \\
\hline & 2014 & 2014 & 2013 & \multicolumn{2}{|c|}{20032014} & 2013 & \multicolumn{2}{|c|}{$\begin{array}{l}1995 \\
2014\end{array}$} \\
\hline Italy & 330 & 43 & 906 & 112 & 97 & 241 & & \\
\hline Germany & 941 & 220 & 1976 & 116 & 124 & 192 & & \\
\hline France & 342 & -72 & 877 & 111 & 107 & 296 & & \\
\hline UK & 259 & -134 & 611 & 123 & 108 & 243 & 48 & 89 \\
\hline Spain & 69 & -25 & 447 & 100 & 93 & 124 & 62 & 98 \\
\hline Netherlands & $\ldots$ & 67 & 309 & 133 & 130 & 186 & 73 & 69 \\
\hline Sweden & 91 & 1 & 217 & 127 & 124 & 299 & 70 & 44 \\
\hline Greece & 8 & -20 & 56 & 93 & 72 & $\ldots$ & $\ldots$ & 177 \\
\hline
\end{tabular}

Sources: EU official statistics. Mean Wealth per capita comes from a survey of the Credit Suisse, Global Wealth databook 2013.

\section{The challenges to be faced}

6 Having said this, there are a number of serious problems with the present Italian industrial basis. The most important ones are in my opinion the following:

- Globalization has offered some advantages to Italian industry, as mentioned before, but has raised also very serious challenges: Italy does not have leading multinationals, with all that this implies. It does have plants from foreign multinationals, which find it interesting to produce in Italy, for reasons which are different from sector to sector, but this is obviously not the same thing, especially, because research is often kept outside Italy. This means that Italian highly qualified young people have often to move abroad to find jobs adequate to their qualification. Italy presently suffers of a serious brain drain.

- All over the world SMEs are administered by families and these are not always ready to managerialize and to provide generational change, producing a high rate of firms shut down, especially as the country shows a great decline in birth rates.

- Italy still has the "Mezzogiorno" problem, the solution of which needs a different approach, after the ages of infrastructures building, of subsidization of capital invested there in capital-intensive plants, and of welfare transfers. The Mezzogiorno does not host many industrial districts and accounts for a very few successful medium size companies, while the former SOEs presence has shrunk everywhere. Probably, industrialization is no longer the appropriate policy, at the exception of agro-industry. Rather, a number of services could be better developed: tourism (including agri-tourism), logistics, ports and sea transportation.

- Politics must be persuaded that public debt is not a way of facing the country problems; on the contrary, it is a way of causing additional problems, as it has happened in the recent crisis. Having a too high public debt accumulated in previous years, the Italian State could 
not support domestic demand which contracted in a drastic way, causing a fall in GDP incomparable with that of most European countries and a dramatic rise in youth unemployment. Reforms are needed to redress competitiveness of the system and possibly allow the strengthening and enlarging of at least some Italian companies.

\section{Conclusions}

7 In my opinion, Italy is now trying to part company from her previous mistakes. The present government seems to have learned some lessons in terms of how to put public finances under control and promote reforms. A more adequate managerialization of SMEs also seems underway, but the road to strengthening big business is still at the very beginning. What is not in sight yet is a change of approach with our Mezzogiorno problem. My hope is that, if the change of our Constitution, which is underway, transforming the Senate in a Chamber of the autonomies will in fact take place, decision making in general will be made more rapid and the responsibilities of Regions and Municipalities directly represented in Parliament to produce wiser projects of development will become clearer.

\section{BIBLIOGRAPHY}

BeLUSSI Fiorenza \& Alessia SAMmARRA (eds), 2009, Business Networks in Clusters and Industrial Districts: The Governance of the Global Value Chain, Routledge, London, $448 \mathrm{p}$.

BeCATTINi Giacomo, Marco BELlANDI \& De Propis Lisa (eds), 2009, A Handbook of Industrial Districts, Elgar, Cheltenham, $863 \mathrm{p}$.

Colli Andrea, 2006, Capitalismo famigliare, Il Mulino 7, Bologna, 155 p.

ColLi Andrea, 2003, The history of family business 1850-2000, CUP, Cambridge, 116 p.

Colli Andrea, 2002, Il quarto capitalismo. Un profilo italiano, Marsilio, Venice, 118 p.

Felice Emanuele, 2015, Ascesa e declino. Storia economica d'Italia, Il Mulino, Bologna, 385 p.

Jones Marian V., Dimitratos Pavlos, Fletcher Margaret \& Stephan Young (eds), 2009, Internationalization, Entrepreneurship and the Smaller Firm: Evidence from around the World, Elgar 16, Cheltenham, $264 \mathrm{p}$.

Mediobanca-Unioncamere, 2009, Le medie imprese industriali italiane (1997-2006), Ufficio studi di Mediobanca, Storia dell'IRI, 1933-2000, 2012-2015, Laterza, Bari.

ZAMAGNI Vera, 1993, Economic History of Italy 1860-1990, Clarendon Press, Oxford, 432 p.

ZAMAGNI Vera, 2009, Finmeccanica. Competenze che vengono da lontano, Bologna: Il Mulino, Bologna, $385 \mathrm{p}$. 


\section{NOTES}

1. There is now (2012-2015) a comprehensive history of IRI in six volumes, Storia dell'IRI (1933-2000), Laterza, Bari.

2. ZAMAGNI, 1993, Felice, 2015, Ascesa e declino. Storia economica d'Italia.

3. ZAMAGNI, 2009.

4. For a general overview of industrial districts, see B ElusSI \& SAMMARRA (eds), 2009; Becattini, Bellandi \& De Propis (eds), 2009; Jones, Dimitratos, Fletcher et al. (eds), 2009, p. 16.

5. Of the 10700 companies examined by the Mediobanca sample of companies with 50499 employees, 1450 were eliminated because they were controlled by large enterprises and 4900 because they did not meet the revenue requirement for medium size companies. Around 4000 form therefore the core of "Fourth capitalism". See Mediobanca-Unioncamere, 2009. The data bank is updated every year.

6. With reference to "Fourth capitalism", see ColLI, 2006, p. 7. See also by the same author, 2003, and 2002.

\section{ABSTRACTS}

The essay presents the original features of Italian entrepreneurship, that, for historical reasons, in so far was mostly focused on developing SMEs (small and medium sized enterprises). To make them internationally competitive, the strategy followed with some success by Italian entrepreneurs has been that of specialization and networking. However, globalization raises challenges that have to be faced through institutional reforms and the consolidation of medium size companies, i.e. the "Fourth capitalism".

Cet essai présente les traits originaux de l'entrepreneuriat italien qui, pour des raisons historiques, s'est jusqu'à présent focalisé sur des PME (Petites et Moyennes Entreprises). Pour les rendre compétitives sur le plan international, les entrepreneurs italiens ont développé avec un certain succès une stratégie de spécialisation et de construction de réseaux. Cependant la globalisation a présenté des défis auxquels il faut faire face par des réformes institutionnelles avec par la consolidation des entreprises de dimension moyenne, c'est-à-dire, le «Quatrième capitalisme ».

Il saggio analizza gli aspetti originali dell'imprenditorialità italiana, che, per ragioni storiche, si è focalizzata finora soprattutto sulle PMI (piccole-medie imprese). Per renderle competitive sul piano internazionale, gli imprenditori italiani hanno sviluppato con un certo successo una strategia di specializzazione e costruzione di reti. Tuttavia, la globalizzazione ha presentato sfide che devono essere affrontate con riforme istituzionali e con il consolidamento delle imprese di medie dimensioni, il "Quarto capitalismo". 


\section{INDEX}

Keywords: industry, entrepreneurship, SMEs (small and medium sized enterprises), specialization, networking, Italy, globalization, contemporary period, economic history, social history

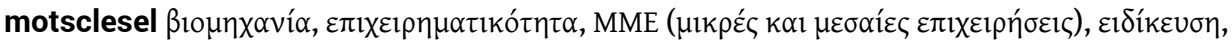

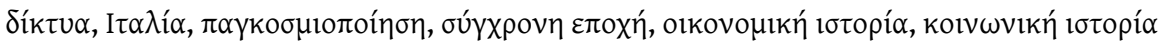
motsclestr sanayi, girişimcilik, KOBI'ler (küçük ve orta ölçekli işletmeler), uzmanlaşma, ağlar, İtalya, küreselleşme, çağdaş dönem, ekonomik tarih, sosyal tarih

Mots-clés: industrie, industrie, entrepreuneriat, entrepreuneriat, PME (petites et moyennes entreprises), PME (petites et moyennes entreprises), spécialisation, spécialisation, réseau, réseau, Italie, Italie, globalisation, globalisation, époque contemporaine, époque contemporaine, histoire sociale, histoire sociale, histoire économique, histoire économique

\section{AUTHOR}

\section{VERA ZAMAGNI}

Professeure, Scuola di Economia, université de Bologne, Italie 